\title{
Eur/Usd Speculative Significance Study: Using an Econometric Model Analyzing Macroeconomic Data Announcements
}

\author{
James Gwarnicki ${ }^{1}$, Sahar Bahmani, Ph.D. ${ }^{2}$ \\ ${ }^{1}$ JP Morgan Chase \& Co \\ ${ }^{2}$ Professor of Finance, University of Wisconsin-Parkside
}

\author{
*Corresponding Author: James Gwarnicki, JP Morgan Chase \& Co, USA
}

\begin{abstract}
This paper investigates the role of macroeconomic variable announcements on the exchange rate of the Euro and US dollar pair (EUR/USD). The EUR/USD pair is traded on the foreign exchange market and the transactions within the asset market affect the exchange rate of a given pair. As advanced economies allocate goods and services, they emit measurable signals, macroeconomic variables, that suggest there is order driving the complexity. Investors trading on the foreign exchange markets assess the data of these variables, GDP, interest rates, inflation, unemployment, to predict the trajectory of the economy. Based on the results of the data, select investors execute trades accordingly. Using an econometric model based on empirical evidence of a theoretical model, aimed to explore the change in exchange rate as a result of scheduled macroeconomic data public announcements. My empirical analysis focuses on the following independent variables; Gross Domestic Product (GDP), interest rate, unemployment, and inflation rates. Numerical data regarding these variables is announced to the public on scheduled dates and times. I entered data from announcements of selected independent variables into a regression analysis program, SAS. My variable coefficients resulted in three variables that proved to be statistically significant; USGDP, EUINT, USINTDUM. The theoretical analysis focuses on the depreciation or appreciation of either currency, as a result of market transactions, following the scheduled news announcement of a given variable.
\end{abstract}

\section{INTRODUCTION}

The importance of studying the methods that may explain future movements in the Euro to United States dollar is evident. The currency pair is seen as one of the most important pairs traded on the foreign exchange market. "Fluctuations in the euro-dollar exchange rate are crucial, not only for the economic transactions between the two major economic blocs, but also for the rest of the countries as both currencies act as a medium of exchange for international transactions, and as an international store of value." (Bianco, 2012) It is no secret among traders and major players in the foreign exchange market that predicting the fluctuations of currency pairs is an extremely difficult practice. This paper will examine the movements of the Euro to U.S. dollar (EUR/USD) exchange rate pair using an econometric model supported by macroeconomic variables collected from both the European Union and the United States. The macroeconomic variables consist of numerical statistics that are released to the public in accordance to a consistent schedule. This schedule is commonly referred to as the economic calendar, a publicly released annual calendar of dates and times for all macroeconomic announcements by country or union.

The information that is contained within the results of scheduled announcements of macroeconomic variables by central banks includes contextual measurements to the condition of a given economy and has the potential to allow investors to speculate on the movement of a currency as it pertains to an exchange rate pair. The data in these announcements can allow for economic theory to be applied based on the positive or negative result of given variables. (possible expand)*

The scheduled United States and European Union macroeconomic announcements are made by the Federal Reserve and the European Union Central Bank (ECB), respectively. A total of four announcements are considered in my analysis: Gross Domestic Product (GDP), Unemployment Rate, Inflation Rate, and Interest Rate. The GDP data announcements are made every fiscal quarter. The unemployment rate and inflation rate is made monthly. Lastly, the model includes interest rate - the U.S. interest rate is announced at each FOMC meeting, which occurs eight times per year and the 
European Union interest rate is reviewed between eight to ten times a year. In Figure 1.2, the frequency and time of the announcement for each economy has been recorded.

It is assumed that investors, or market participants, who react to such macroeconomic data announcements base their observations off of a certain expectation or estimate. The expectation of each variable may be based on the historical average, the natural rate, or a trusted estimate. This study does not factor in estimates, as have past studies, but does consider the natural rate, as well as decreasing or increasing trends as included in my theoretical analysis.

The rest of the paper is organized as follows: Section 2 describes the macroeconomic variables that I have chosen for the econometric model as they pertain to providing a dependable measure of the condition of their respected economy. Section 3 illuminates the empirical model including an econometric model that is computed using a regression analysis software, also included is the methodology and data used in the study. Section 4 focuses on my theoretical analysis which looks at each macroeconomic variable on its own and how that will affect the exchange rate. In section 5 I discuss the empirical results of the coefficient variance values of the independent variables computed in the regression analysis. Lastly, Section 6 specifies conclusions highlighting the statistically significant variables and a forward look at derived policy recommendations.

\section{MACROECONOMiC VARIABLES}

A fundamental requirement of any model is that a strong correlation between the dependent and explanatory variables exist when applying economic theory. The following macroeconomic variables data announcements have been collected to analyze potential significance on the movement of the EUR/USD exchange rate pair.

\section{United States Gross Domestic Product (GDP)}

The inclusion of this variable is to measure United States economic growth. Gross Domestic Product refers to the sum of all goods and services produced in the United States. Statistics that provide evidence of steady and consistent growth levels are optimal for developed nations. Real GDP which is what I looked at is equal to the economic output adjusted for the growth of inflation in the U.S. economy. Investors typically look at these numbers to determine if an economy is experiencing positive economic growth or recessionary values.

The mean average of the quarterly total U.S. GDP for the period of March 2013 through February 2019 was 18.4 trillion dollars. The lowest amount in the period collected was 16.6 trillion U.S. dollars and the highest was 20.7 trillion U.S. dollars. The data followed an upward trend over the entire period and did not have any anomalies, as shown in figure 1.4.

\section{European Union GDP}

The variable was included in the model because it provides a measure of European Union economic growth. Gross Domestic Product refers to the sum of all goods and services produced in the European Union. Statistics that provide evidence of steady and consistent growth levels are optimal for developed nations. Such statistics can prove to be reliable for foreign exchange market traders. Real GDP which is what I looked at is equal to the economic output adjusted for the growth of inflation in the European Union economy. Investors typically look at these numbers to determine if an economy is experiencing positive economic growth or recessionary numbers.

The mean average of the quarterly total European Union GDP for the period of March 2013 through February 2019 was 3.67 trillion Euros. The lowest amount in the period collected was 3.2 trillion Euros and the highest was 3.9 trillion Euros. The data followed an upward trend over the entire period and did not have any outliers, as shown in figure 1.5.

\section{United States Interest Rate}

The inclusion of this variable is in response to the monetarist view that money supply is the most important determinant of interest rate, and will commonly be used as a monetary policy in response to economic activity. Such activity includes a low growth period following a recession will trigger a monetary policy commonly known as a expansionary policy. Interest rate is measured in percentage points and represents the return on an invested sum of money on a yearly basis. The interest rate for United States based investments is set by the Federal Reserve, specifically the Federal Open Market Committee. 
The mean average of U.S. interest rates for the period of March 2013 through February 2019 was 0.76 percent. The lowest amount in the period collected was 0.25 percent and the high was 2.50 percent. The data followed an upward trend over the entire period and did not have any outliers, as shown in figure 1.6.

\section{European Union Interest Rates}

Interest rate is measured in percentage points and represents the return on an invested sum of money on a yearly basis. The interest rate for European Union based investments is set by the European Central Bank (ECB), which is recognized as the central bank for all member countries within the European Union. The complexity of a currency union is reflected in the actions of interest rate adjustment. However, much of the policies enacted by the United States are carried out by the ECB when the European Union begins to experience parallel growth patterns. During the time period of data collected for my research, the ECB has lowered interest rates and maintained the low position.

The mean average for European Union interest rates for the period of March 2013 through February 2019 was 0.11 percent. The lowest amount in the period collected was 0 percent and the highest was 0.75 percent. The data followed a downward trend over the entire period and did not have any outliers, as shown in figure 1.7.

\section{United States Inflation Rates}

Inflation is a quantitative measure of the rate at which the average price level of a basket of selected goods and services in an economy increases over a period of time. Often expressed as a percentage, inflation rates are an indicator of a change in the purchasing power of the United States dollar. As an economy experiences a period of high or low growth the inflation rate will often follow a predictable route. This pattern in the percentage values of data collected will provide valuable insight on the health of an economy.

The mean average of quarterly total U.S. GDP for the period of March 2013 through February 2019 was 1.92 percent. The lowest amount in the period collected was 1.6 percent and the highest was 2.4 percent. The data shows a slow upward trend over the entire period and did fluctuate away from the trend line in both directions, as shown in figure 1.8.

\section{European Union Inflation Rates}

Inflation is a quantitative measure of the rate at which the average price level of a basket of selected goods and services in an economy increases over a period of time. Often expressed as a percentage, inflation rates are an indicator of a change in the purchasing power of the European Union Euro. As stated above the patterns of inflation rates in an economy like the United States will model a similar pattern for European Union rates.

The mean average of monthly European Union inflation rates for the period of March 2013 through February 2019 was 0.9 percent. The lowest amount in the period collected was 0.5 percent while the highest was 2.3 percent. The data shows an upward trend at the beginning of the time period and roughly halfway through the data began to trend upward, as shown in figure 1.9.

\section{United States Unemployment Rate}

The unemployment rate is the ratio of the number of people that are unemployed to the number of people in the labor force that are eligible for employment. The ratio is expressed as a percentage and is calculated by dividing the number of people unemployed by the total eligible people in the U.S. labor force.

The mean average of monthly U.S. unemployment rates for the period of March 2013 through February 2019 was 5.28 percent. The lowest amount in the period collected was 3.7 percent while the highest was 8 percent. The data shows a downward trend over the entire period and did not have any outliers, as shown in figure 1.10 .

\section{European Union Unemployment Rate}

The mean average of the monthly European Union unemployment rate for the period of March 2013 through February 2019 was 10.32 percent. The lowest amount in the period collected was 7.9 percent 
Eur/Usd Speculative Significance Study: Using an Econometric Model Analyzing Macroeconomic Data Announcements

while the highest was 12.1 percent. The data shows a downward trend over the entire period and did not have any outliers, as shown in figure 1.11 .

\section{Data And Methodology}

The data collected for this research carries an importance requiring the dates of the announcements to be precise and accurate. That required the date and the time of the announcement to be consistent with the variable statistics collected. United States data was collected from the Federal Reserve central bank database, Federal Reserve Economic Database (FRED). European Union data was collected from the for the Eurostat website, sourced by the European Central Bank (ECB). The model is designed to capture the movement of trading on a given market day. That being the movement of the EUR/USD exchange rate pair on the date the announcement is made. The dates of announcements would then be matched with the market quote rate for the coinciding trading day. Market data represented the EUR/USD exchange rate at the closing quote price for the New York market. Foreign exchange quote prices were collected from the FRED database. A total of 1,556 trading days were recorded which ranged from Monday through Friday for the period of 2013 to 2019. In the excel spreadsheet was a total of sixteen columns. All but the date for each column can be found in figure 1.1 below.

Figure 1.1

\begin{tabular}{|l|l|}
\hline \multicolumn{2}{|c|}{ Table One } \\
\hline$Y=D E X U S E U$ & List of Variables \\
\hline USGDP & Euro to U.S. Dollar Exchange Rate at New York market closing rate. \\
\hline EUGDP & United States Gross Domestic Product Rate \\
\hline USINT & European Union Gross Domestic Product Rate \\
\hline USINTDUM & United States Interest Rate \\
\hline EUINT & United States Interest Rate Adjustment \\
\hline EUINTDUM & European Union Interest Rate \\
\hline USINF & European Union Interest Rate Adjustment \\
\hline EUINF & United States Inflation Rate \\
\hline USEMP & European Union Inflation Rate \\
\hline EUEMP & United States Employment Rate \\
\hline DayM & European Union Employment Rate \\
\hline DayT & Dummy variable for day of week Monday \\
\hline DayW & Dummy variable for day of week Tuesday \\
\hline DayTH & Dummy variable for day of week Wednesday \\
\hline
\end{tabular}

Model: $\_$DEXUSEU $=\beta \mathrm{o}+\beta 1$ USGDP $+\beta 2$ EUGDP $+\beta 3$ USINT $+\beta 4$ USINTDUM $+\beta 5$ EUINT $\beta 6 E$ EINTDUM + $\beta 7 U$ SINF $+\beta 8 E$ UINF $+\beta 9$ USEMP $+\beta 10 E U E M P+\beta 11$ DayM $+\beta 12$ DayT $+\beta 13$ Day $W+\beta 14$ DayTH

Figure 1.2

\begin{tabular}{|l|l|l|l|l|}
\hline & \multicolumn{3}{|c|}{ United States Announcements } \\
\cline { 2 - 5 } & $\begin{array}{l}\text { Gross Domestic } \\
\text { Rate Product (GDP) }\end{array}$ & Interest Rates & Inflation Rate & Unemployment \\
\hline $\begin{array}{l}\text { Frequency } \\
\text { announcements }\end{array}$ & Six-week cycle & Monthly & Monthly \\
\hline $\begin{array}{l}\text { Source of announced } \\
\text { figures/data }\end{array}$ & QRED & FRED & FRED & FRED \\
\hline Unit of measurement & $\begin{array}{l}\text { Quarterly Total } \\
\text { Recorded in billions }\end{array}$ & Percentage & Percentage & Percentage \\
\hline $\begin{array}{l}\text { Announcement Time } \\
\text { Time period }\end{array}$ & $\begin{array}{c}\text { March 2013- } 7: 30 \text { a.m. } \\
\text { February 2019 }\end{array}$ & $\begin{array}{l}\text { March 2013- } \\
\text { February 2019 }\end{array}$ & $\begin{array}{l}\text { March 2013- } \\
\text { February 2019 }\end{array}$ & 7:00 a.m. \\
\hline $\begin{array}{l}\text { Total number of } \\
\text { announcements within } \\
\text { data period }\end{array}$ & 23 & February 2019 \\
\hline
\end{tabular}


Eur/Usd Speculative Significance Study: Using an Econometric Model Analyzing Macroeconomic Data Announcements

Figure 1.3

\begin{tabular}{|c|c|c|c|c|}
\hline & \multicolumn{4}{|c|}{ European Union Announcements } \\
\hline & \begin{tabular}{|l} 
Gross Domestic \\
Product (GDP)
\end{tabular} & Interest Rates & Inflation Rate & Unemployment Rate \\
\hline $\begin{array}{c}\text { Frequency of } \\
\text { announcements }\end{array}$ & Quarterly & Ranging cycle & Monthly & Monthly \\
\hline $\begin{array}{c}\text { Source of } \\
\text { announced } \\
\text { figures/data }\end{array}$ & Eurostat & Eurostat & Eurostat & Eurostat \\
\hline $\begin{array}{c}\text { Unit of } \\
\text { measurement }\end{array}$ & $\begin{array}{l}\text { Quarterly Total } \\
\text { Recorded in } \\
\text { millions }\end{array}$ & Percentage & Percentage & Percentage \\
\hline $\begin{array}{c}\text { Announcement } \\
\text { Time }\end{array}$ & 4:00 a.m. & 4:00 a.m. & 4:00 a.m. & 4:00 a.m. \\
\hline Time period & $\begin{array}{l}\text { March } 2013- \\
\text { February } 2019\end{array}$ & $\begin{array}{c}\text { March 2013- } \\
\text { February } 2019\end{array}$ & $\begin{array}{l}\text { March 2013- } \\
\text { February } 2019\end{array}$ & $\begin{array}{r}\text { March 2013- } \\
\text { February } 2019\end{array}$ \\
\hline $\begin{array}{l}\text { Total number of } \\
\text { announcements } \\
\text { within data period }\end{array}$ & 73 & $\mathrm{xx}$ & $\mathrm{xx}$ & $\mathrm{xx}$ \\
\hline
\end{tabular}

\section{U.S. GDP}

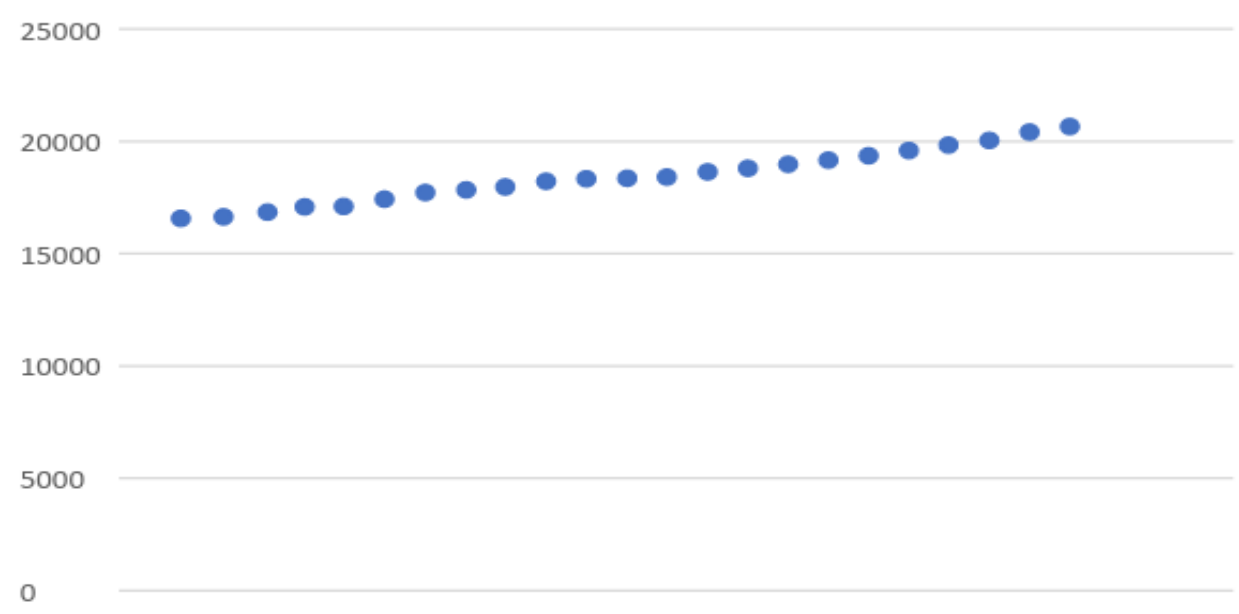

Figure 1.4

EU GDP

4500000

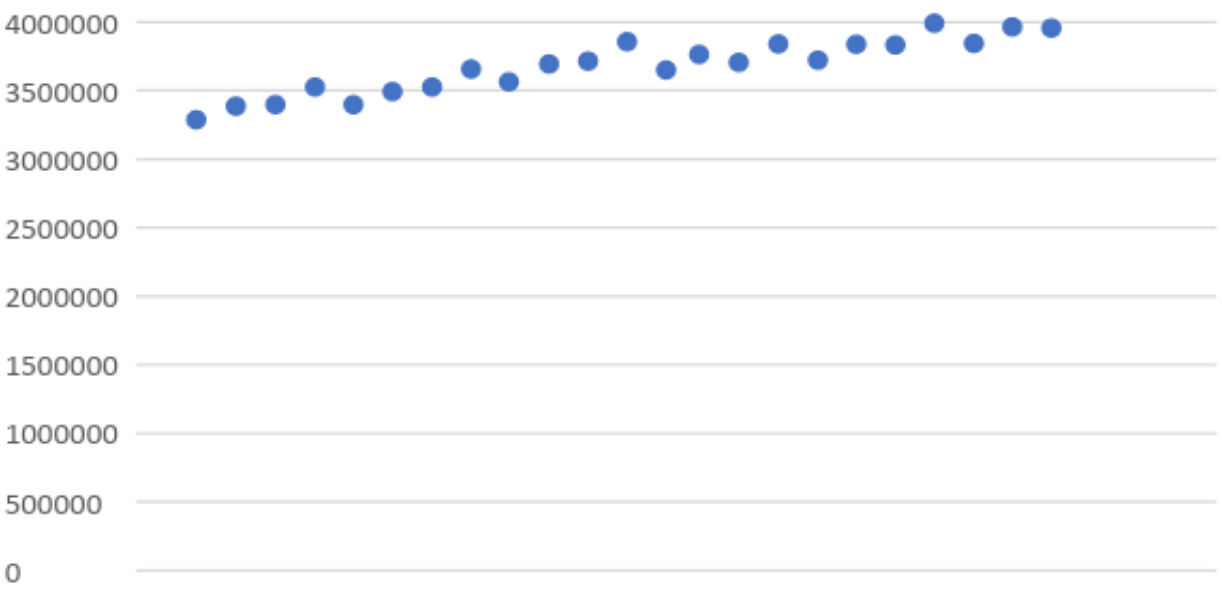

Figure 1.5 
Eur/Usd Speculative Significance Study: Using an Econometric Model Analyzing Macroeconomic Data Announcements

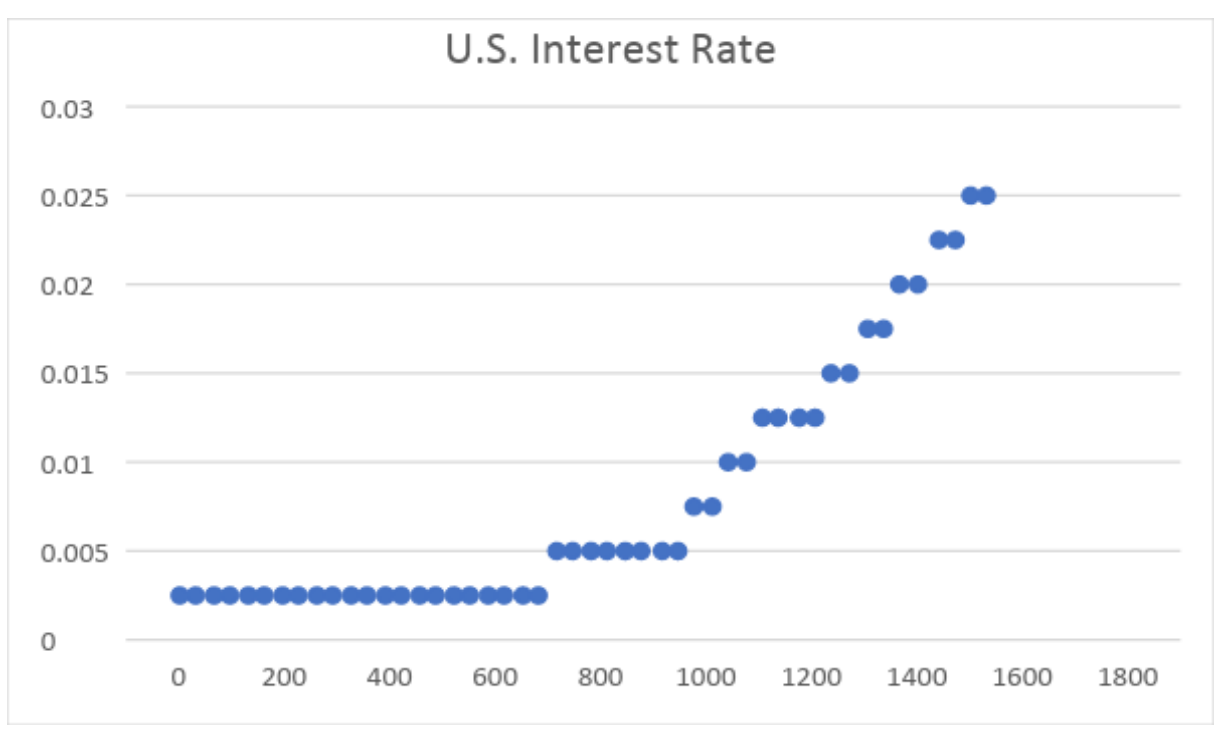

Figure 1.6

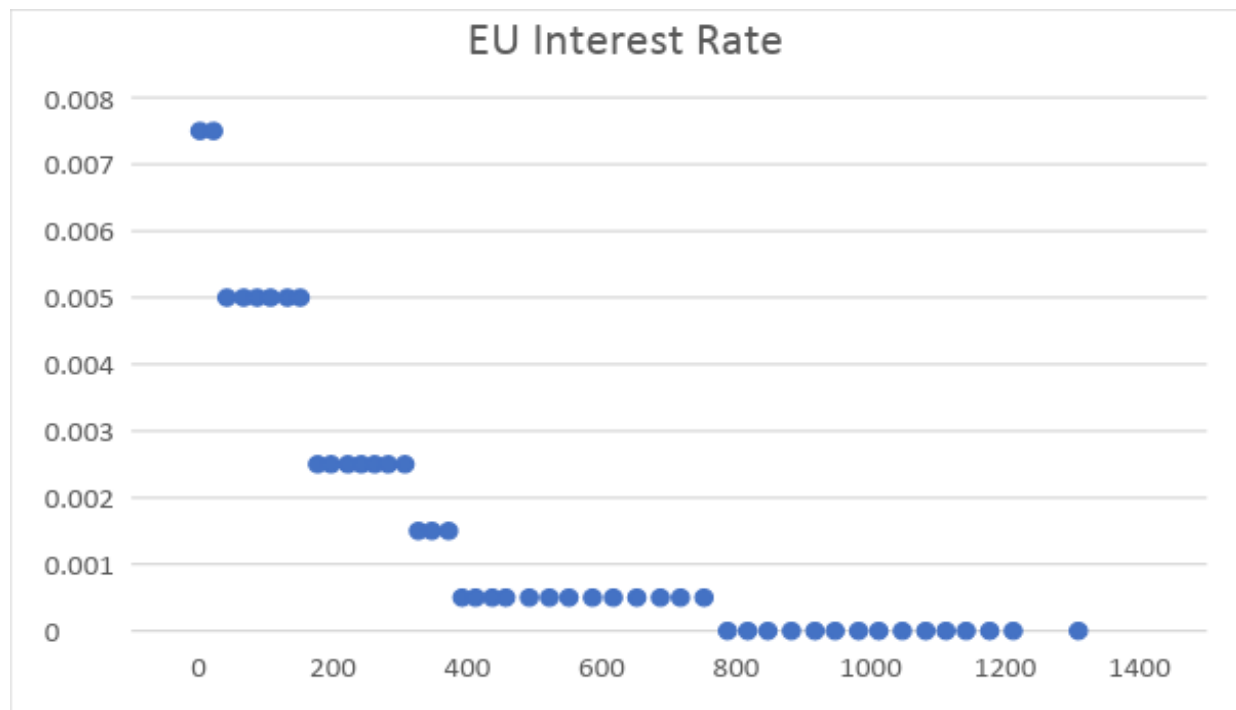

Figure 1.7

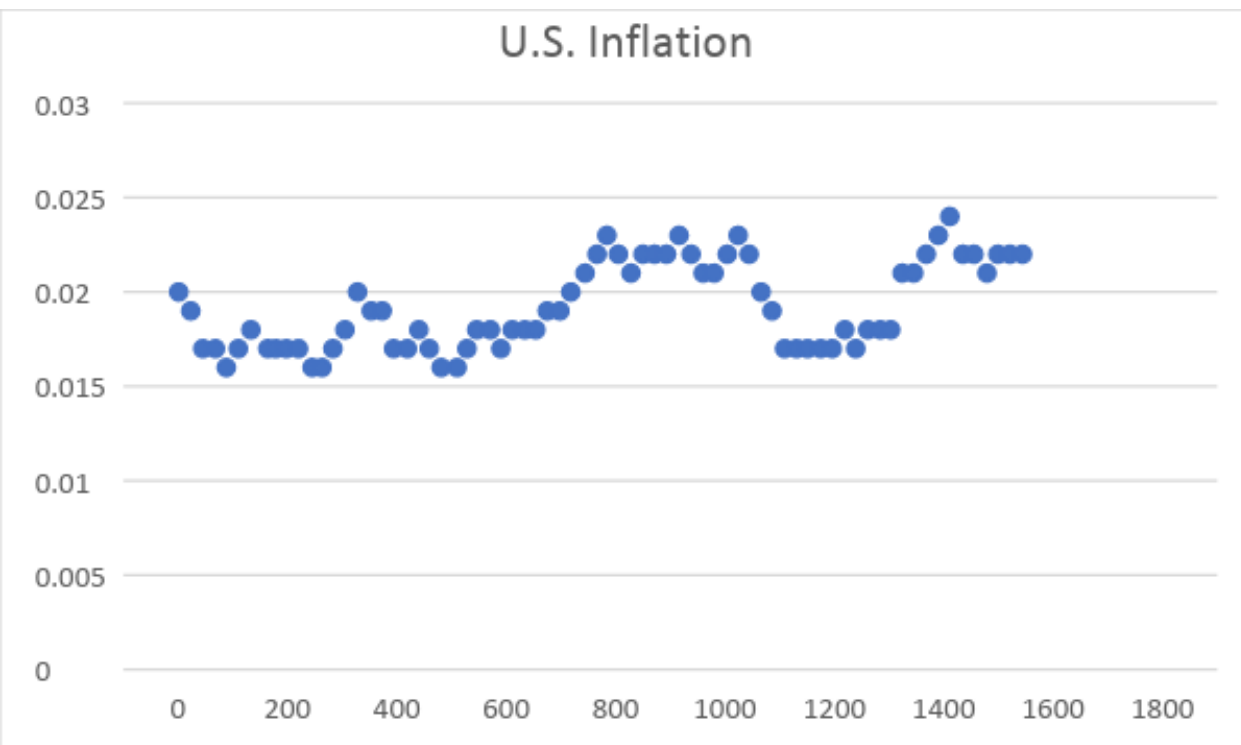

Figure 1.8 
Eur/Usd Speculative Significance Study: Using an Econometric Model Analyzing Macroeconomic Data Announcements

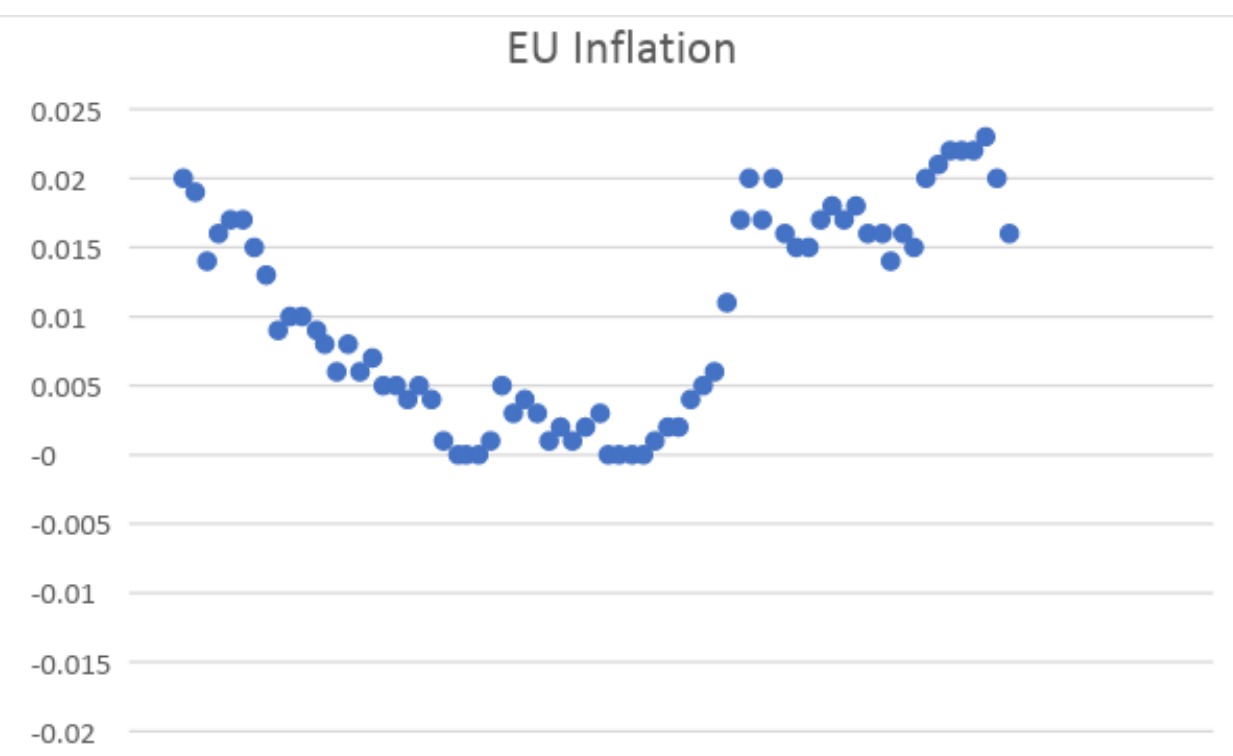

Figure 1.9

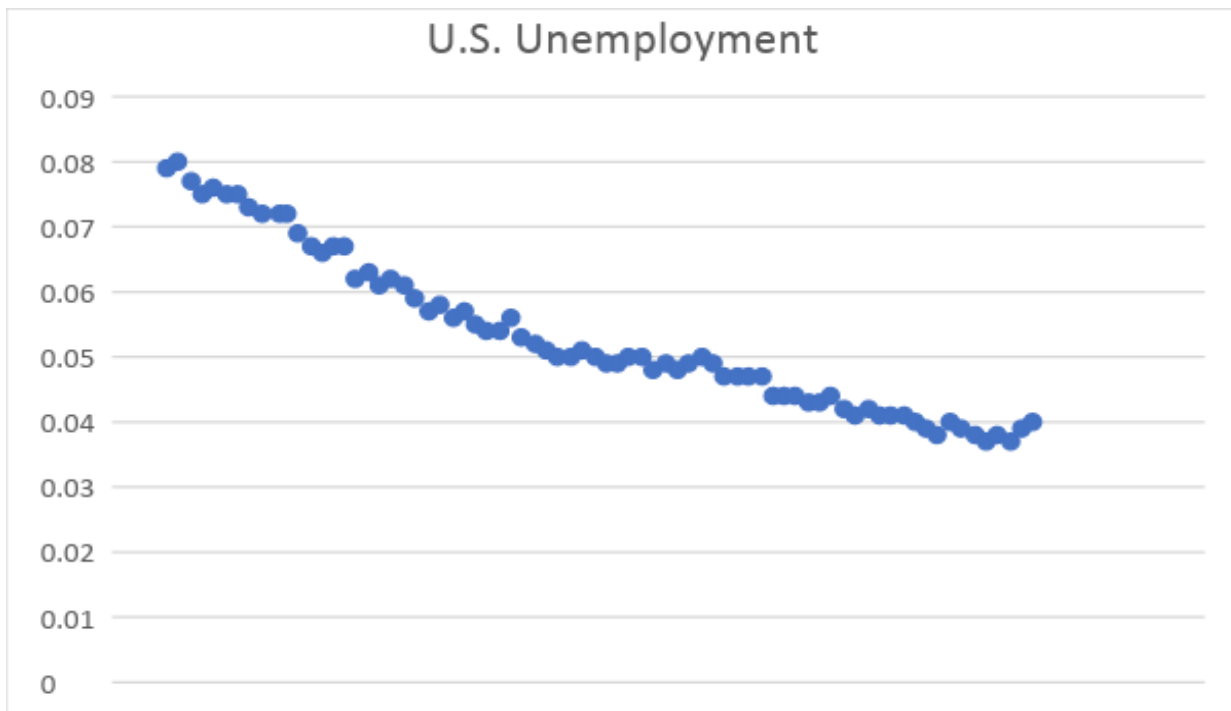

Figure 1.10

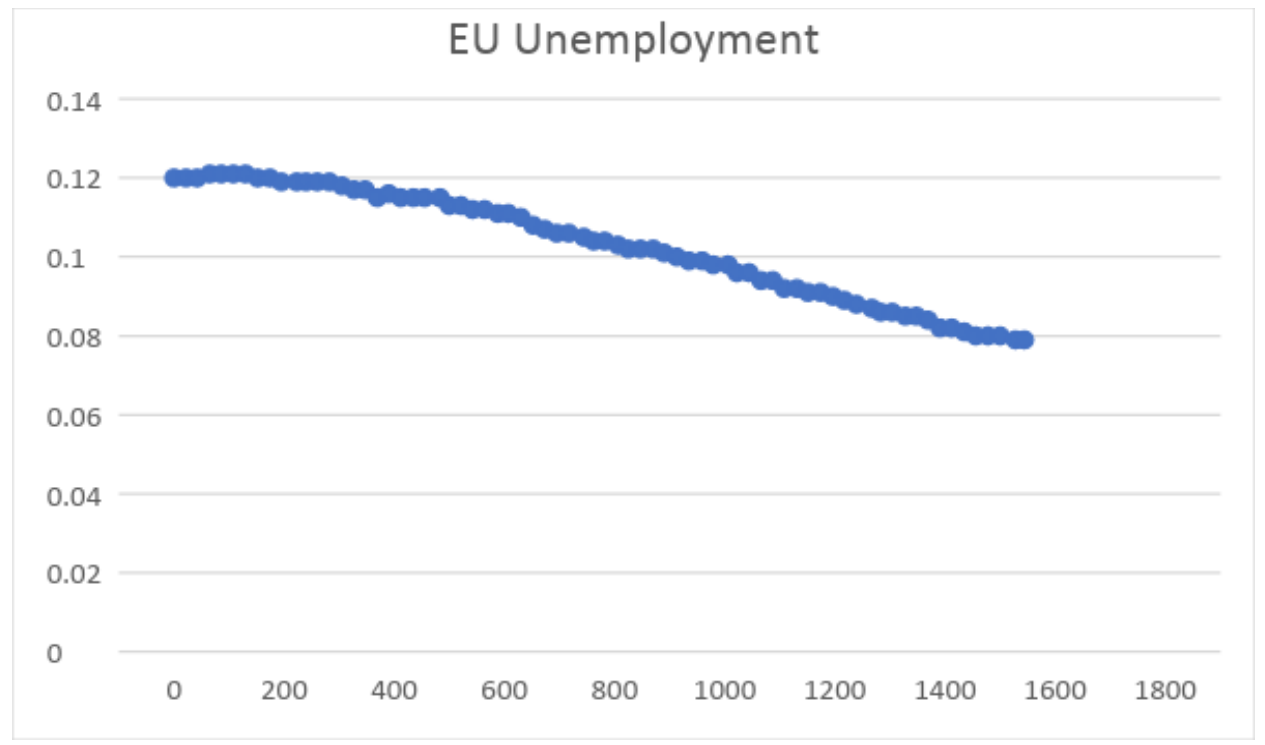

Figure 1.11 


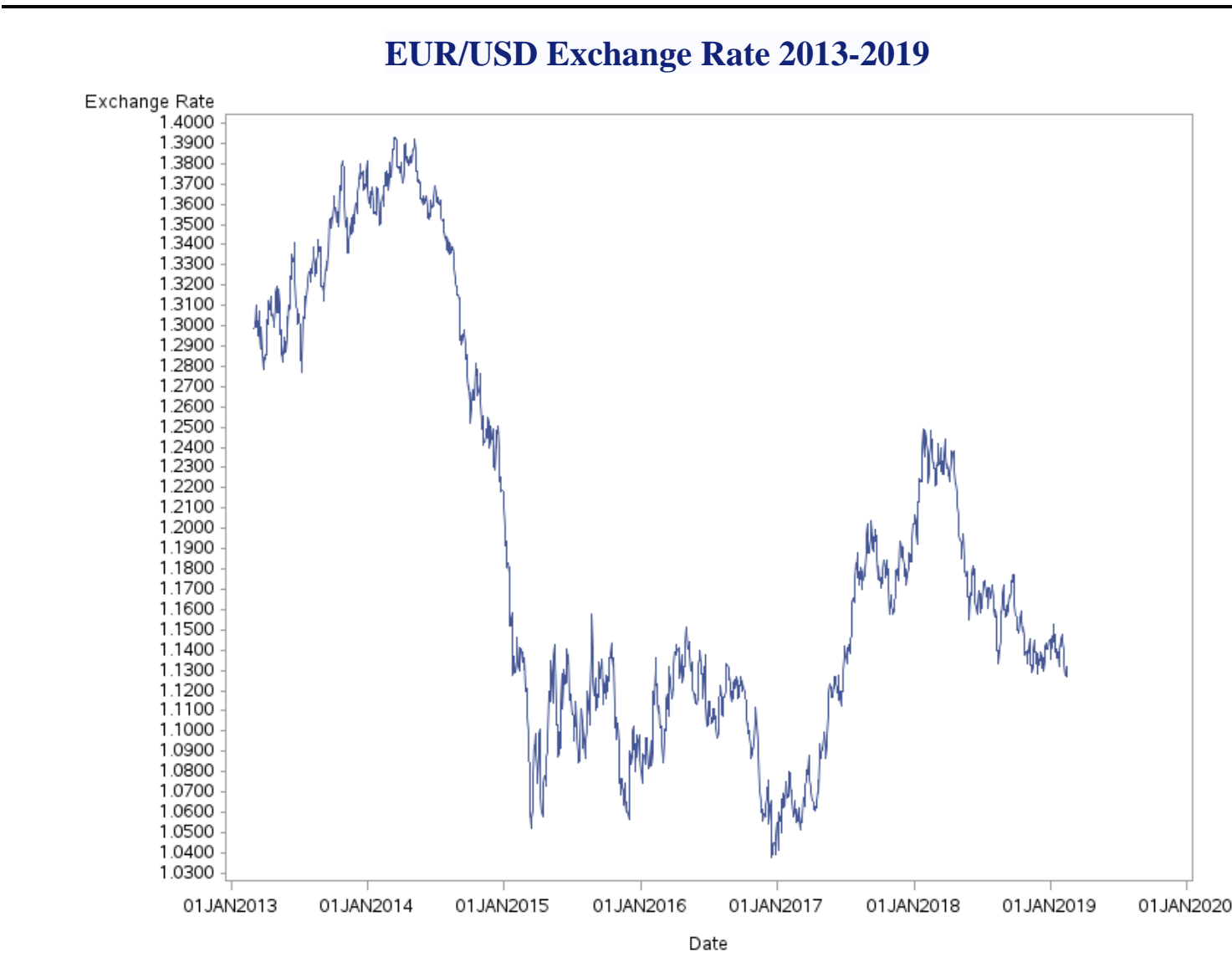

Figure 1.12

\section{TheOretical ANALYSIS}

The theoretical analysis for this research follows that of economic theory as opposed to strictly viewing movements in the exchange rates from the perspective of a foreign exchange rate trader. My research aims to gauge the relevance of economic theory in the behavior of traders contributing to the exchange rate movements. Changes in expected future values of market fundamentals contribute to exchange-rate volatility in the short run. The variables that have been chosen, Gross Domestic Product, Interest Rate, Unemployment Rate, and Inflation Rate, are believed to change expectations in the demand and supply of each currency. The aim of the study is to measure the statistical significance of the chosen macroeconomic variables news announcements as potential factors of movement in the Euro to U.S. dollar exchange rate quote price. Exchange rates tend to be highly sensitive to current demand and supply conditions. Currency rates often depreciate or appreciate more in the short run than in the long run so as to compensate for other prices that are slower to adjust to their long-run equilibrium levels. Short run theory will prove to be relevant in my theoretical analysis since the regression analysis is computing the variance coefficients of variables for a dependent variable recorded on the present day market close quote price.

The movements are believed to follow the direction that coincides with the theorized appreciation and depreciation of a single currency. This section will analyze the United States dollar with each variable representing a reciprocal response for the European Union Euro. Economic theory suggests when a given macroeconomic variable portrays positive growth for an economy, the fiat currency will appreciate. When the currency of a nation or union is theorized to appreciate, we would then expect the demand for that currency in the foreign exchange market to increase.

Movement of the exchange rate pair quote price is a result of an increase in buy side transactions of one currency and an simultaneous increase in the sell side transactions of another currency. For instance, when the demand of the U.S. dollar is increasing, the market is experiencing a increase in the selling of the Euro and increase in the purchasing of the U.S. dollar. As a trader executes a position to buy a currency, they are simultaneously selling the other currency in the pair. So, as one is buying the U.S. dollar they are selling the Euro. As A.D. Cohen states in his academic paper, an 
econometric model for foreign exchange rate forecasting, "The relationship between supply and demand is a focal point behind the choice of variables...all factors which go to make up and affect currency supply and demand are of the first most importance in considering movements in rates of exchange.” (Cohen, 2015)

With relation to the macroeconomic scheduled news announcements of United States Gross Domestic Product (GDP), when an increase in the quarterly data is posted, this can be interpreted as a strengthening economy that is experiencing positive output growth. Such output growth can result in, higher levels of consumer consumption, increased investment, increased income and wages, higher amounts of capital, and more. Hence the equation for the sum of GDP which is equal to the value of the goods and services produced in an economy over a period of time. The data collected for this study is based on annual cycles of GDP sum totals. The statistics inputted into the data for the regression model is the GDP quarterly growth totals.

If GDP is to be recorded as an amount that is greater than the last quarter, I theorize that the EUR/USD exchange rate will decrease. The decrease will result in increased trade demand for the U.S. dollar and increased supply of the Euro increases, thus dropping the quote price of the EUR/USD exchange rate. When European Union GDP data is announced on a quarterly basis, I would theorize that results which model positive growth in the European Union economy are released then the trade demand for the Euro will increase while the supply of the U.S. dollar increases. This reaction in the exchange rate market would result in an increased EUR/USD quote price. All quote prices are equal to the New York market close price.

The theory consistent with the United States unemployment rate supports the understanding that low unemployment is the result of a robust economy. Economists tend to favor analyzing the unemployment rate for the information it contains about a given economy. The rate can be a signal that the economy may or may not be utilizing its resources efficiently. The reason is that when unemployment is low the economy is experiencing high output and high consumption. During such a period, the resources of the economy are at equilibrium and being efficiently utilized. When resources are operating at equilibrium the production of an economy is increasing. The opposite is happening when a large number of workers are searching for employment cannot find jobs, in that case the economy is not utilizing its labor and capital efficiently and unemployment rates are high.

My theory as it applies to the change in the EUR/USD exchange rate predicts that when the U.S. unemployment rate is released at a level below the expected rate of 5\% for the U.S. that the EUR/USD exchange rate pair will decrease. My theoretical analysis also supports a decrease in the exchange rate when the release of data over a period of time is trending at a decreasing rate, even if it is above the natural rate. The decrease in the EUR/USD quote price is a result of market movement due to an increase in the U.S. dollar demand and an increase in the Euro supply.

The inflation rate variable included is intended to show the appreciation or depreciation of the currency and its correlation with the output of the economy. If output is less than the natural level of output than the price level is less than the expected price level. Output will be below the equilibrium output level set by aggregate demand and aggregate supply curves. An increase in output increases the price level. An increase in output leads to an increase in employment. An increase in employment leads to a decrease in unemployment and a decrease in the unemployment rate. Firms will set a higher nominal wage, thus leading to an increase in the prices set by firms and therefore an increase in the price level. This increase in the price level is also known as increased inflation levels. When the above is occurring, the economy is operating at an efficient level and investors will react positively to the numbers.

My theory suggests that a scheduled release of the U.S. inflation rate, resulting in an increase in the change in inflation will be interpreted as the byproduct of a healthy economy. This will lead investors to increase the demand for the U.S. dollar and increase the supply of the Euro which will decrease the quote price of the EUR/USD exchange rate. An increase in the European Union inflation rate will cause the EUR/USD exchange rate to increase because of an increase in the demand for the Euro and an increase in the supply of the U.S. dollar.

The response to United States interest rates is expected to carry a significant influence on the EUR/USD exchange rate. Central banks commonly adjust interest rates as a form of monetary policy. 
Eur/Usd Speculative Significance Study: Using an Econometric Model Analyzing Macroeconomic Data Announcements

Such a policy will affect the money supply of an economy. Interest rates are evaluated by the United States central bank, the Federal Reserve, eight times per year. For the European Central Bank the amount of meetings fluctuated between eight to ten times per year, during the period recorded. When the central bank hold meetings to discuss rate levels, rates remain unchanged the majority of the time. I theorize that when the interest rate meetings occur for the United States the market will experience a decrease in the EUR/USD rate. This can only be theorized when the market interest rates are low and trending upward as was the case during this period. A higher interest rate will increase the demand for foreign investment within the given economy.

Although, these news releases hold significance themselves they have less significance on the exchange rate when left unchanged. For this reason I have included a dummy variable to capture the significance of central bank meetings when the interest rate is adjusted. I theorize that when the interest rate meetings occur and an adjustment is made for the United States the market will experience a decrease in the EUR/USD rate. When United States interest rates increase the dollar will experience an increase in demand and the euro supply will increase. The theory is following the assumption that the interest rate hikes are trending upward. When a meeting occurs in which rates are adjusted foreign investors and traders will increase trade demand for the currency which has increased its interest rates. In addition, economic theory supports the notion that when an economy is performing well and inflation is increasing the central bank should slow the appreciation of the currency through an increase in the interest rate. In the short run an increase in the interest rates is will carry a signal that the economy is operating at a high level and will not cause a major depreciation of the currency.

The reciprocal response will occur when the European Union is experiencing the same results and computing the same values for the macroeconomic variables stated above. The reciprocal response will occur in the European Union for the following variables: GDP, unemployment rate, inflation rate, and interest rate.

Figure 1.12

\section{Regression Analysis with Autoregressive Errors}

\section{The AUTOREG Procedure}

\begin{tabular}{|l|l|l|l|}
\hline Yule-Walker Estimates & 0.05647697 & DFE & 1540 \\
\hline SSE & 0.0000367 & Root MSE & 0.00606 \\
\hline MSE & -11371.582 & AIC & -11457.18 \\
\hline SBC & 0.00454993 & AICC & -11456.826 \\
\hline MAE & 0.38648085 & HQC & -11425.35 \\
\hline MAPE & 1.8860 & $\begin{array}{l}\text { Transformed Regression } \\
\text { R-Square }\end{array}$ & 0.0523 \\
\hline Durbin-Watson & & Total R-Square & 0.9965 \\
\hline
\end{tabular}

\begin{tabular}{|l|l|}
\hline Durbin-Watson Statistics \\
\hline Order & DW \\
\hline 1 & 1.8860 \\
\hline
\end{tabular}

\begin{tabular}{|c|c|c|c|c|c|}
\hline \multicolumn{6}{|c|}{ Parameter Estimates } \\
\hline Variable & $\mathrm{DF}$ & Estimate & Standard Error & T Value & Approx $\operatorname{Pr}>|t|$ \\
\hline Intercept & 1 & 1.5061 & 0.1541 & 9.77 & $<0001$ \\
\hline USGDP & 1 & -0.000016 & $5.8819 \mathrm{E}-6$ & -2.72 & 0.0066 \\
\hline EUGDP & 1 & $-2.189 \mathrm{E}-9$ & $1.1519 \mathrm{E}-8$ & -0.19 & 0.8493 \\
\hline USEMP & 1 & 0.4403 & 0.4451 & 0.97 & 0.3335 \\
\hline EUEMP & 1 & -0.1153 & 0.6263 & -0.18 & 0.8540 \\
\hline USINF & 1 & -1.2954 & 0.7220 & -1.79 & 0.0730 \\
\hline EUINF & 1 & 0.3351 & 0.3093 & 1.08 & 0.2787 \\
\hline USINT & 1 & -1.2366 & 0.9849 & -1.26 & 0.2095 \\
\hline USINTDUM & 1 & 0.006144 & 0.001916 & 3.21 & 0.0014 \\
\hline EUINT & 1 & 8.2788 & 1.9118 & 4.33 & $<.0001$ \\
\hline
\end{tabular}


Eur/Usd Speculative Significance Study: Using an Econometric Model Analyzing Macroeconomic Data Announcements

\begin{tabular}{|l|l|l|l|l|l|}
\hline EUINTDUM & 1 & 0.001952 & 0.002403 & 0.81 & 0.4168 \\
\hline DayM & 1 & 0.000206 & 0.000311 & 0.66 & 0.5063 \\
\hline DayT & 1 & -0.000085 & 0.000383 & -0.22 & 0.8234 \\
\hline DayW & 1 & -0.000335 & 0.000386 & -0.87 & 0.3852 \\
\hline DayTH & 1 & 0.000290 & 0.000316 & 0.92 & 0.3583 \\
\hline
\end{tabular}

\section{EMPIRICAL ANALYSIS - ECONOMETRIC MODEL}

The dependent variable for the regression model is the quote price (DEXUSEU), which represents the New York closing exchange rate price for the EUR/USD pair. The estimate for this variable is measured in U.S. dollars. Based on the variables that have been included, I believe that my model will have a strong fit and represent an accurate measure of the exchange rate regression. The type of model that I will use to interpret my independent variables is a multivariate time-series regression analysis with auto correlated error terms. The independent variables included are as follows. United States Gross Domestic Product (USGDP), European Union Gross Domestic Product (EUGDP), U.S. Interest Rate (USINT), European Union Interest Rate (EUINT), U.S. Inflation (USINT), European Union Inflation (EUINF), U.S. Unemployment (USEMP), European Union Unemployment (EUEMP). The variables listed above coincide with the explanation and theoretical analysis provided for each. In my econometric model, I have included six dummy variables to better capture the accuracy that my model wished to represent. Those included are; U.S. Interest Rate Dummy variable (USINTDUM), European Union Interest Rate Dummy variable (EUINTDUM), and trading days Monday through Friday (DayM, DayT, DayW, DayTH).

\section{INTERPRETATION OF STATISTICAL RESULTS OF THE REGRESSION}

The empirical statistical analysis was computed using the SAS program to measure the variable intercept relationship between the independent and dependent variables in my econometric model. The overall fit for the model, or an R-squared of 99.65 percent was calculated to measure the proportion of variation in the response data explained by the predictors in the model. I performed a Durbin-Watson test to detect any evidence of auto-correlation between the independent variables in this model. The result was a value of 1.8860 allowing for my model to not reject the null hypothesis of a model suggesting evidence of autocorrelation.

As for the variable intercepts in my econometric model, the following recorded a parameter estimate holding the other explanatory variables in my model constant. An increase of one billion U.S. dollars in U.S. GDP the EUR/USD exchange rate decreased by 0.000016 dollars, ceteris paribus (holding other explanatory variables constant). An increase of one million dollars in European Union GDP, decreased the EUR/USD exchange rate by 2.18 dollars, ceteris paribus. An increase in the U.S. unemployment rate of one percentage point recorded an increase in the EUR/USD exchange rate of 0.4403 dollars, ceteris paribus. An increase in the European Union unemployment rate of one percentage point recorded a decrease in the EUR/USD exchange rate of 0.1153 dollars, ceteris paribus. An increase in the U.S. inflation rate of one percentage point recorded a decrease in the EUR/USD exchange rate of 1.2954 dollars, ceteris paribus. An increase in the European Union inflation rate of one percentage point recorded an increase in the EUR/USD exchange rate of 0.3351 dollars, ceteris paribus. An increase in the U.S. interest rate of one percentage point recorded a decrease in the EUR/USD exchange rate of 1.2366 dollars, ceteris paribus. An increase in the European Union interest rate of one percentage point recorded an increase in the EUR/USD exchange rate of 8.2788 dollars, ceteris paribus. Excluding the dummy variables for the days of the week, the two other dummy variables are important to include in my review of the data. The dummy variables created for the U.S. interest rate and European Union interest rate data are included to recognize the days when the central banks did adjust the interest rates. The variable USINTDUM can be interrupted as for the central bank meetings when an interest rate adjustment was announced the EUR/USD exchange rate pair increased by 0.006144 dollars, ceteris paribus. When the European Central Bank adjusted the interest rate the EUR/USD exchange rate increased by 0.001952 dollars, ceteris paribus.

Lastly, and certainly worth noting was the significance of the corresponding independent variables. At a confidence level of $95 \%$ the critical value for the respected degrees of freedom is 1.960 . Under that T-critical value the variables representing U.S. GDP (USGDP), U.S. interest rate adjustment (USINTDUM), and European Union interest rates (EUINT) were found to be statistically significant towards the overall fit of my econometric model. In other terms, when running a four-step hypothesis 
test on the significance of the variables, I was able to reject the null hypothesis. This informed me that the variables USGDP, USINTDUM, and EUGDP were statistically significant from the value zero.

For variables that a market reaction is proven to be statistically significant when the regression is run can potentially hint toward trading algorithms that would be used on dates that statistically significant variable are scheduled to be released. These algorithms or trading strategies would execute a position in the market prior to the announcement, with the intention of minimizing speculative risk on trades forecasting the movement of the exchange rate following an announcement. Although my empirical analysis did not perform forecast coefficients for a given future period the variables with a $t$-value within the level of significance can be analyzed for such a purpose.

\section{CONCLUSION WITH POLICY IMPLiCATIONS}

My research concludes that announcements for the variables representing U.S. GDP, EU interest rate, and U.S. interest rate adjustments were statistically significant. Policy recommendation that may improve the significance of the EU variables would be to create a fiscal union to better complement the currency union.

An issue that my model faced was the dominance of countries such as Germany, France, and the United Kingdom undermining the use of European Union data. My intention was to gather data on the entire European Union and the United States economy for my chosen macroeconomic variables. That being said, I am aware a common practice amongst traders and researchers is to gather economic data directly from the juggernaut countries within the European Union. The reason is that smaller countries and the struggling economies are tainting the data collected from the European Union as a whole. In the coming months a likely brexit will initiate a restructuring of the policies and relations amongst the [twenty-five] countries of the European Union. Ulrich Krotz and Joachim Schild share their opinion in the Journal of European Public Policy, "The more assertive and exclusive the Franco-German leadership ambition, the more resistance it is likely to meet among the other 25 members." (Krotz and Schild, 2018). Policy that promotes balancing macroeconomic factors can help the accuracy and scale of data, but also begin to distribute the unbalanced budget and employment totals within the European Union. Coalitions have begun amongst the smaller countries and in order for a successful outcome there must be like-minded participation from Germany and France.

\section{REFERENCES}

[1] Pillin, Punitkumar. "A Survey on the Determination of Nominal Exchange Rate for USD Vis-à-Vis INR.” SSRN Electronic Journal, 2018, doi:10.2139/ssrn.3257239.

[2] Krotz, Ulrich, and Joachim Schlid. "France and Germany Will Dominate the EU after Brexit - but They Won't Go Unchallenged." EUROPP, 9 May 2019, blogs.lse.ac.uk/europpblog/2019/01/30/france-andgermany-will-dominate-the-eu-after-brexit-but-they-wont-go-unchallenged/.

[3] A. D. Cohen (1978) An econometric model for foreign exchange rate forecasting, Investment Analysts Journal,7:12, 32-36, DOI: 10.1080/10293523.1978.11082617

[4] Marcos dal Bianco, Maximo Camacho and Gabriel Perez-Quiros. Short-Run Forecasting of the EuroDollar Exchange Rate with Economic Fundamentals. Banco De Espana, Madrid. 2012.

[5] "Federal Reserve Economic Data, FRED, St. Louis Fed." FRED, Federal Reserve Bank of St. Louis, fred.stlouisfed.org/.

[6] "Your Key to European Statistics." Home - Eurostat, 2019, ec.europa.eu/eurostat/web/main/home.

[7] Economic Calendar, 2019, tradingeconomics.com/calendar\#.

[8] Carbaugh, Robert J. International Economics. South-Western Cengage Learning, 2013.

Citation: James Gwarnicki, Sahar Bahmani, Ph.D." Eur/Usd Speculative Significance Study: Using an Econometric Model Analyzing Macroeconomic Data Announcements" International Journal of Humanities Social Sciences and Education (IJHSSE), vol 8, no. 2, 2021, pp. 15-26. doi: https://doi.org/10.20431/2349. 0381.0802003 .

Copyright: (C) 2021 Authors. This is an open-access article distributed under the terms of the Creative Commons Attribution License, which permits unrestricted use, distribution, and reproduction in any medium, provided the original author and source are credited. 